\title{
Potential Species Distribution and Richness of Ixodidae Ticks Associated with Wild Vertebrates from Michoacán, Mexico
}

\author{
Margarita Vargas-Sandoval ${ }^{*}$, Angel G. Priego-Santander ${ }^{2}$, Alejandra Larrazábal2 ${ }^{2}$, \\ Carolina G. Sosa-Gutiérrez ${ }^{3}$, Blanca Lara-Chávez ${ }^{1}$, Teresita Avila-Val1 \\ ${ }^{1}$ Facultad de Agrobiología "Presidente Juárez", Universidad Michoacana de San Nicolás de Hidalgo, Uruapan, \\ México \\ ${ }^{2}$ Centro de Investigaciones en Geografía Ambiental, UNAM, Antigua Carretera a Pátzcuaro No. 8701, \\ ExHacienda de San José de la Huerta, Morelia, México \\ ${ }^{3}$ Unidad de Investigación Médica de Enfermedades Infecciosas y Parasitarias, Hospital de Pediatría, Centro \\ Médico Nacional Siglo XXI, México, DF, México \\ Email: *vargasmarga@yahoo.com.mx
}

Received 28 July 2014; revised 28 August 2014; accepted 20 September 2014

Copyright (C) 2014 by authors and Scientific Research Publishing Inc.

This work is licensed under the Creative Commons Attribution International License (CC BY).

http://creativecommons.org/licenses/by/4.0/

(c) (i) Open Access

\section{Abstract}

Ticks are regarded as the most relevant vectors of disease-causing pathogens in domestic and wild animals. The diversity of Ixodidae is known for a very small number of genera. Ixodes are represented by 26 species, and in 2007 the first reported ticks vectors in Mexico for the causal agent of Lyme disease. Recent rise in tick-borne disease in many parts of the world is a phenomenon in need of an explanation. The main objective of the present work was to map at a regional scale $(1: 2,000,000)$ of the distribution of ticks of the family Ixodidae that are potentially present on the wild fauna of state of Michoacan, Mexico. We compiled all available literature on ticks at a national level together with complete cartographic and bibliographic georeferenced information of the distribution of hosts in order to build a spatial database in ArcView 3.3. The results indicated that the wild fauna in the state's territory could potentially include 31 species of ticks of Ixodidae. The map of potential species richness of ixodid ticks on the wild fauna of the state can be categorized into five classes of species richness. The highest potential concentration of ixodid species on wild fauna occurs in the volcanic area of Pico de Tancítaro.

\section{Keywords}

Ticks, Ixodidae, Michoacán, Geographic Distribution, Potential Species Richness

\footnotetext{
"Corresponding author.
}

How to cite this paper: Vargas-Sandoval, M., Priego-Santander, A.G., Larrazábal, A., Sosa-Gutiérrez, C.G., Lara-Chávez, B. and Avila-Val, T. (2014) Potential Species Distribution and Richness of Ixodidae Ticks Associated with Wild Vertebrates from Michoacán, Mexico. Journal of Geographic Information System, 6, 467-477. http://dx.doi.org/10.4236/igis.2014.65040 


\section{Introduction}

Ticks (Acari: Ixodida) are external parasites of terrestrial vertebrates that feed on blood and tissue of their hosts; and are considered to be the second only to mosquitoes worldwide vectors of human diseases, but they are regarded as the most prevalent vectors of disease-causing pathogens in domestic and wild animals [1], and transmit more pathogen species than any other group of blood-feeding arthropods worldwide [2]. In cases of high infestations, blood loss can be sufficiently extensive to cause the death of small animals [3]. For the development and implementation of control strategies, it is important to identify the vector ticks and their transmission pattern of the pathogens in the target geographical region [4]. However, damage caused by ticks may be still more important because they are vectors of pathogenic organisms that are directly transmitted to vertebrates during attachment and feeding, or indirectly through contact with tick fluids released with the products of coxal glands or with feces.

Ticks are grouped into three families: Argasidae (193 species), Ixodidae (702 species) and Nuttalliellidae (monotypic) [5]. Only the first two families are known from Mexico.

Ticks have been reported by indigenous since Pre Hispanic times, including the Tarascas people from Michoacán, Mexico; who called them turicata [6] [7]. However, knowledge of the number of tick species and of their distribution in Mexico is very scarce. The diversity of Ixodidae is known for a very small number of genera. In Mexico some specilist [8], one of the most species-rich genera worldwide recorded 26 species of Amblyomma. Ixodes are represented by 26 species [9] [10], Vargas and cols [11] for the first time reported in Mexico species Ixodidae vectoring the causal agent of Lyme disease, the spirochatae Borrelia burgdorferi and added six new ixodid species records for the country. Hoffmann and Lopéz-Campos [12] recorded 52 valid species of 5 genera for Mexico. Since then, 23 records have been added, accumulating a total of 75 species in 5 genera of Ixodidae known from Mexico [9]-[11].

In Michoacán, as in certain other states from Mexico, problems associated with the drug trade make it unsafe for biologist to collect in certain areas. In addition, high rates of changes in environment and land use [13] are causing local extinctions and changes in distribution of wildlife that are hosts of many species of ticks. For these reasons, predictive models can be useful tools for estimating the potential distribution of ixodid tick species, and thus infer their species richness in Michoacán and other regions of Mexico. Furthermore, because the ticks are vectors disease agents that affect humans and their domestic animals, the possibility of particular species can alert health authorities to confirm suspected cases of zoonosis in the reservoir hosts and vector ticks predicted to occur in the region [14] [15].

Maping the distribution of ticks using published records, field inventories and environmental factors such as vegetation type or land use, has been successful in explaining the spatial distribution of ticks, as often prognostic maps are based on the distribution of covariates such as land use, where high correlations were obtained between observed and expected geographic distribution [16] [17].

The objectives of this study were using literature records, our field work and environmental features to create maps of the potential distribution of tick species of the family Ixodidae associated with wildlife in Michoacán, and to develop spatial estimators of their potential richness using cartographic hypothesis; they will help to direct future geographic.

\section{Materials and Methods}

\subsection{Study Area}

The state of Michoacán forms part of Central Western Mexico, approximately between $18^{\circ} 09^{\prime}$ and $20^{\circ} 23^{\prime}$ north latitude and $103^{\circ} 44^{\prime}$ and $100^{\circ} 04^{\prime}$ west longitude. It encompasses $58,370 \mathrm{~km}^{2}$ [18] and represents $3 \%$ of the land area of Mexico. It includes nearly $217 \mathrm{~km}$ of coastline along the Pacific Ocean between the mouths of the Balsas and the Coahuayana Rivers. To the north it abuts with the states of Jalisco and Guanajuato, to the northeast with Querétaro, to the east with the state of México, to the southeast with Guerrero, to the west with Colima and to the southwest, with the Pacific Ocean (Figure 1).

In order to know the potential geographic distribution of ixodid ticks in Michoacán the following methodology was carried out:

\subsubsection{Literature and Cartographic Survey}

To obtain a list of potential hosts of ixodids in Michoacán, we performed a literature review of ixodids and their 


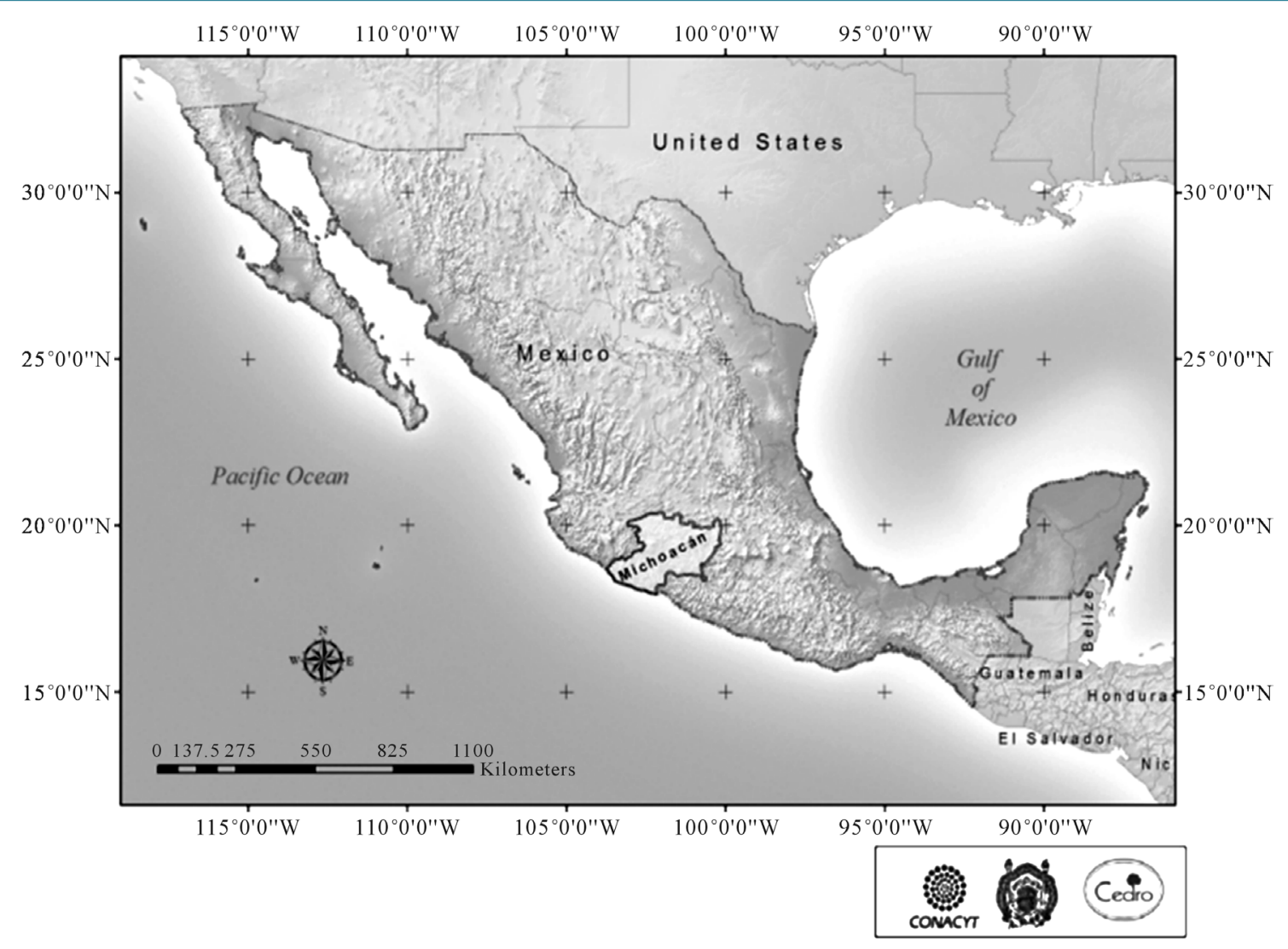

Figure 1. Geographic localization of Michoacán state in Mexico.

hosts as recorded for Mexico was carried out as well as the species of amphibians, reptiles, birds and mammals recorded in Michoacán, and with which ticks have been associated. In all potential hosts, the association supports the evidence host-parasite relationship recorded for Mexico [8]-[12] [19]-[25]. The cartographic survey involved compilation of the most recent geological maps, relief, climate, soils and vegetation and land use [26][30] available for the study area, and georeferenced data on the distribution of terrestrial vertebrate wildlife in Michoacán [31]. The contours of vegetation and land use are assumed as polygons to display the distribution of potential hosts.

\subsubsection{Field Surveys Conducted}

We collected a number of new locality and host recorded for ixodes in Michoacán in Nuevo Urecho $\left(101^{\circ} 52^{\prime} \mathrm{W}\right.$, $19^{\circ} 09^{\prime} \mathrm{N}, 5$ July 2009) we collected one female and 10 male Amblyomma imitator on vegetation with a sweep net. In Aquila (3.2 km, $19.5 \mathrm{KmW}$ Aquila, $130 \mathrm{~m}$, December 19, 1990) rodent were collected with Shermann traps and were placed in individual plastic bags and frozen in dry ice to be transported and reviewed in the laboratory under a stereomicroscope. From these we found one nymph and one female A. maculatum on the ear of Sigmodon hispidus (Muridae), which were extracted with fine forceps. From a farm in the town of Coahuayana (Management Unit for conservation of wildlife UMA, $103^{\circ} 41^{\prime} 47.5^{\prime \prime} \mathrm{W}, 18^{\circ} 39^{\prime 2} 28.6^{\prime \prime} \mathrm{N}, 4 \mathrm{~m}$, May 29, 2009) we collected one male and one female $A$. dissimile on Iguana iguana. All ticks were placed in $70 \%$ alcohol and were identified under a stereoscopic microscope using the available literature [19]-[22] [32] [33] in the Laboratory of Acarology “Isabel Bassols”, National School of Biological Sciences, National Polytechnic Institute and verified determination in laboratory scientific collection.

\subsubsection{Database Production}

With all the above information, we prepared a geo-referenced database containing information on the vertebrates present on Michoacán and the tick species reported in literature on Michoacán and those collected during the fieldwork, all with the geographic coordinates for processing platform ArcView 3.3 [34]. 
The production of predictive maps: to create the maps of Potential Distribution of ixodid species, all the points having fieldwork, reported in literature and potential hosts of ixodid were plotted on the map of the state of Michoacán and individual maps for each tick species were generated at a 1:250,000 scale. To find out if there were any spatial relationships between landscape components and distribution of ticks and their hosts, we performed map overlaid of these maps in the GIS and thus try to find some spatial patterns. Were used geological maps, relief, climate, soils and vegetation and land use [26]-[30].

To create the map of Potential Species Richness for ixodids in Michoacán, a five-class cartogram was prepared by the method of natural breaks [34] using the information in the previously made maps referred to vegetation cover and land use polygons that were predictive of the habitat of the hosts. All the spatial information was integrated, processed and edited with the support of the Geographic Information System ArcView 3.3. The working scale was 1:250,000 and the final edition was made at a 1:2,000,000 scale, considering the density of available information.

\section{Results}

Factors affecting the distribution of tick ectoparasites of terrestrial vertebrates are the same that affect the distribution of their hosts. Thus, the hypothesis of potential distribution was estimated taking into account the prior record of the species in Mexico, its association with wild vertebrate or registered in the state and the information from six ecological variables: geological, relief, climate (annual precipitation maximum and minimum) temperature, soil, vegetation and land use change.

With the information, were generated individual maps by species at 1:250,000 scale for 31 species of ticks (Table 2). Four examples of these maps are presented for Ixodes tancitarus, Ixodes texanus, Amblyomma parvum and Dermacentor occidentalis (Figure 2).

In Table 1 we summarizes the species of ixodids reported in literature and those collected during our
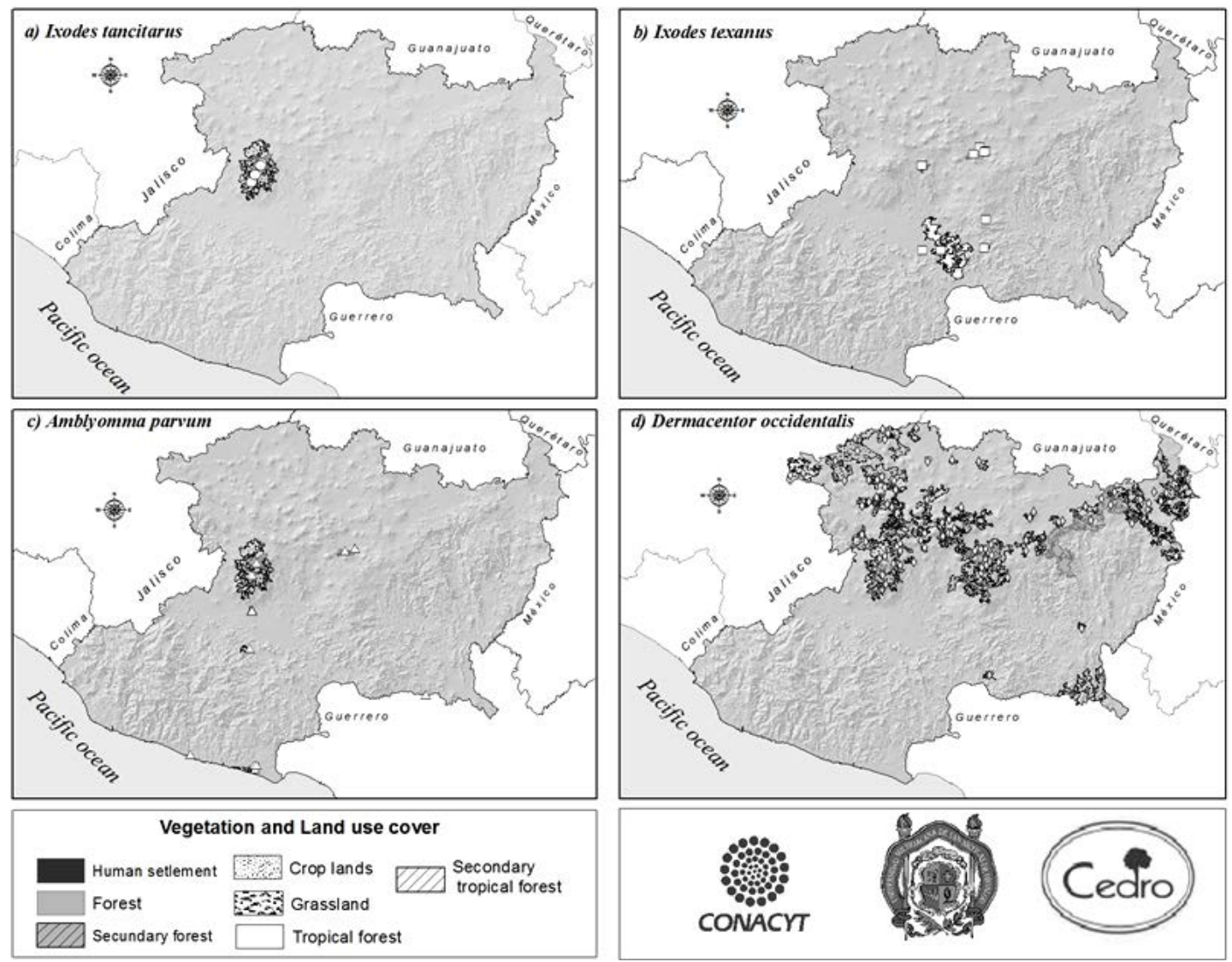

Figure 2. Potential distribution of Ixodes tancitarus, Ixodes texanus, Amblyomma parvum and Dermacentor occidentalis from Michoacan, Mexico. 
Table 1. Ixodidae ticks reported in literature and those collected during the fieldwork in the state of Michoacán.

\begin{tabular}{|c|c|c|c|}
\hline Ixoxidae & Host & Locality & Reference \\
\hline \multirow[t]{2}{*}{$\begin{array}{l}\text { Ixodes mexicanus Cooley } \\
\quad \text { and Kohls, } 1942\end{array}$} & $\begin{array}{c}\text { Heleodyctes gularis sic (=Campylorhynchus } \\
\text { gularis, birds: Troglodytidae) }\end{array}$ & Michoacán & Hoffmann and López-Campos, 2000 \\
\hline & Junco phaeonotus (Birds: Emberizidae) & Cerro Tancítaro & Guzmán-Cornejo et al., 2007 \\
\hline \multirow[t]{2}{*}{$\begin{array}{l}\text { I. tancitarus Cooley and } \\
\text { Kohls, } 1942\end{array}$} & Reithrodontomys sp. (Rodentia: Muridae) & Cerro Tancitaro & Cooley and Kohls, 1942 \\
\hline & Reithrodontomys sp. & Cerro Tancítaro & $\begin{array}{l}\text { Hoffmann and López-Campos, 2000; } \\
\text { Guzmán-Cornejo et al., } 2007\end{array}$ \\
\hline \multirow[t]{2}{*}{$\begin{array}{l}\text { Amblyomma auricularium } \\
\text { (Conil, 1878) }\end{array}$} & Dasypus novemcintus (Xenarthra: Dasypodidae) & Michoacán & $\begin{array}{c}\text { Hoffmann and López-Campos, 2000; } \\
\text { Jones et al., } 1972\end{array}$ \\
\hline & Bufo marinus (Amphibia: Bufonidae) & & Hoffmann and López-Campos, 2000 \\
\hline \multirow[t]{2}{*}{ A. dissimile Koch, 1844} & Iguana iguana (Sauropsida: Iguanidae) & Tumbiscatio & Gaxiola et al., 1997 \\
\hline & & Coahuayana & Authors’ fieldwork \\
\hline A. imitator Kohls, 1958 & Not a host & New Urecho & Authors' fieldwork \\
\hline A. maculatum Koch, 1844 & Sigmodon sp. (Rodentia: Muridae) & Aquila & Authors’ fieldwork \\
\hline A. parvum Aragao, 1908 & & Tumbiscatio & Gaxiola et al., 1997 [39] \\
\hline A. rotundatum Koch, 1844 & Phrynosoma sp. (Sauropsida: Phrynosomidae) & Michoacán & Hoffmann and López-Campos, 2000 \\
\hline $\begin{array}{l}\text { Dermacentor albipictus } \\
\quad \text { (Packard, 1869) }\end{array}$ & Deer, horses, cows & Michoacán & Hoffmann and López-Campos, 2000 \\
\hline
\end{tabular}

Note: Dermacentor albipictus was not incorporated into predictive map.

fieldwork in the state of Michoacán. A total of nine species of the family were found being present in the state’s territory.

Considering the wild vertebrate fauna of Michoacán, the results of field inventory and the previous report of those tick species in Mexico and Michoacan, a total of 31 ixodid species likely to be associated with wild vertebrates in this state (Table 2). Given that 75 species of the family Ixodidae are known for Mexico, our analysis suggests that $44.3 \%$ of these species might be present in Michoacán, even though it represents only 3\% of Mexico's territory. This marked disproportion points to the importance of further collection and research on ixodids in Michoacán, more so when it is considered that this prediction is restricted to wild vertebrates and hence excludes the ticks present in cattle and other domestic animals.

As indicated in Table 2, taking into account the hosts, there is a whole spectrum of tick's spatial distribution of Ixodidae family, with species whose hosts have to date more than 120 collection record, and others less than 10. Considering that not all ticks species have high host specificity, suggests that some species of ticks may have a greater distribution than the potential distribution mapped here, while others may be very restricted. In particular it may be observed that Ixodes tancitarus is a strict local endemic [9], and just been collected in the Pico de Tancítaro volcano (which gave origin to its specific name).

The unresolved taxon Ixodes sp. had the largest number of hosts, with five in total, but since it has not been determined at species level, introduces uncertainty about the total number of species involved (one or more). In this case it is necessary to wait until the taxonomic analyses are completed before its geographic distribution in the state may be determined.

Figure 3 shows the spatial distribution of all known records of ixodid genus and hosts in Michoacán, and potential ixodid and hosts for the state at a regional scale of 1:2,000,000.

\section{Discussion}

By overlaying in the GIS maps of natural components (climate, geology, topography, soils, vegetation and land use) the following general statements may be made from the results of the GIS analysis: 
Table 2. Ticks of the family Ixodidae, potentially and current found in wild fauna from Michoacan.

\begin{tabular}{|c|c|c|}
\hline Tick species & Collection points of hosts & Recorded and potential hosts of ticks in Michoacán \\
\hline Amblyomma auricularium ${ }^{*}$ & 30 & Dasypus novemcinctus $(\mathrm{M})^{*}$, Bufo marinus $(\mathrm{A})^{*}$ \\
\hline Amblyomma dissimile $^{*}$ & 60 & Iguana iguana $(\mathrm{R})^{*}$, Kinosternon integrum $(\mathrm{R})$ and Bufo marinus \\
\hline Amblyomma maculatum ${ }^{*}$ & 16 & Urocyon cinereoargenteus (M), Sigmodon sp. (M)* \\
\hline Amblyomma oblongoguttatum & 14 & Odocoileus virginianus (M) \\
\hline Amblyomma parvum* & 14 & Dasypus novemcinctus \\
\hline Amblyomma rotundatum ${ }^{*}$ & 40 & $\begin{array}{l}\text { "Phrynosoma asio }(\mathrm{R}), \text { Phrynosoma coronatum }(\mathrm{R}) \text {, } \\
\text { Dasypus novemcinctus }{ }^{*} \text { and Bufo marinus }\end{array}$ \\
\hline Amblyomma scutatum & 31 & Ctenosaura similis $(\mathrm{R})$ and Ctenosaura pectinata $(\mathrm{R})$ \\
\hline Dermacentor andersoni & 25 & Neotoma mexicana $(\mathrm{M})$ \\
\hline Dermacentor halli & 15 & Lepus callotis (M) \\
\hline Dermacentor occidentalis & 97 & Peromyscus melanophrys (M) and Peromyscus maniculatus (M) \\
\hline Dermacentor parumapertus & 32 & Peromyscus melanosis (M), Lepus callotis and Perognathus flavus (M) \\
\hline Dermacentor variabilis & 15 & Lepus callotis \\
\hline Haemaphysalis leporispalustris & 132 & Crotophaga sulcirostris (B), Sylvilagus floridanus (M) and Lepus callotis \\
\hline Ixodes affinis & 4 & Nasua narica (M) \\
\hline Ixodes augustus & 25 & Neotoma mexicana \\
\hline Ixodes boliviensis & 30 & Urocyon cinereoargenteus and Odocoileus virginianus \\
\hline Ixodes cookei & 26 & Bassariscus astutus (M) and Urocyon cinereoargenteus \\
\hline Ixodes cuernavacensis & 6 & Streptoprocne semicollaris (B) \\
\hline Ixodes dentatus & 53 & Sylvilagus floridanus \\
\hline Ixodes eadsi & 82 & Liomy sirroratus $(\mathrm{M})$ \\
\hline Ixodes kingi & 27 & Spermophilus variegates (M) \\
\hline Ixodes luciae & 37 & Didelphis virginiana $(\mathrm{M})$ \\
\hline Ixodes marxi & 63 & Sciurus aureogaster (M) \\
\hline Ixodes mexicanus* & 37 & Campylorhynchus gularis (B) and Junco phaeonotus (B) \\
\hline Ixodes rubidus & 129 & $\begin{array}{c}\text { Peromyscus maniculatus, Bassariscus astutus, Spermophilus variegatus } \\
\text { and Urocyon cinereoargenteus }\end{array}$ \\
\hline Ixodes scapularis & 53 & Sylvilagus floridanus \\
\hline Ixodes sinaloa & 160 & Oryzomys couesi (M) and Liomys pictus (M) \\
\hline Ixodes sp. & 136 & $\begin{array}{l}\text { Liomys pictus, Sorex saussurei (M), Peromyscus difficilis (M), } \\
\text { Reithrodontomys microdon (M) and Peromyscus melanocarpus (M) }\end{array}$ \\
\hline Ixodes spinipalpis & 53 & Sylvilagus floridanus \\
\hline Ixodes texanus & 10 & Bassariscus astutus \\
\hline Ixodes tancitarus* & 9 & Reithrodontomys chrysopsis (M) and Reithrodontomys sumichrasti (M) \\
\hline Ixodes tovari & 15 & Lepus callotis \\
\hline
\end{tabular}

The hosts are amphibians (A), reptiles (R), mammals (M), and birds (B). "Indicated known records of ixodid species and hosts in Michoacán; taxa without asterisks are predicted to occur in this state. 


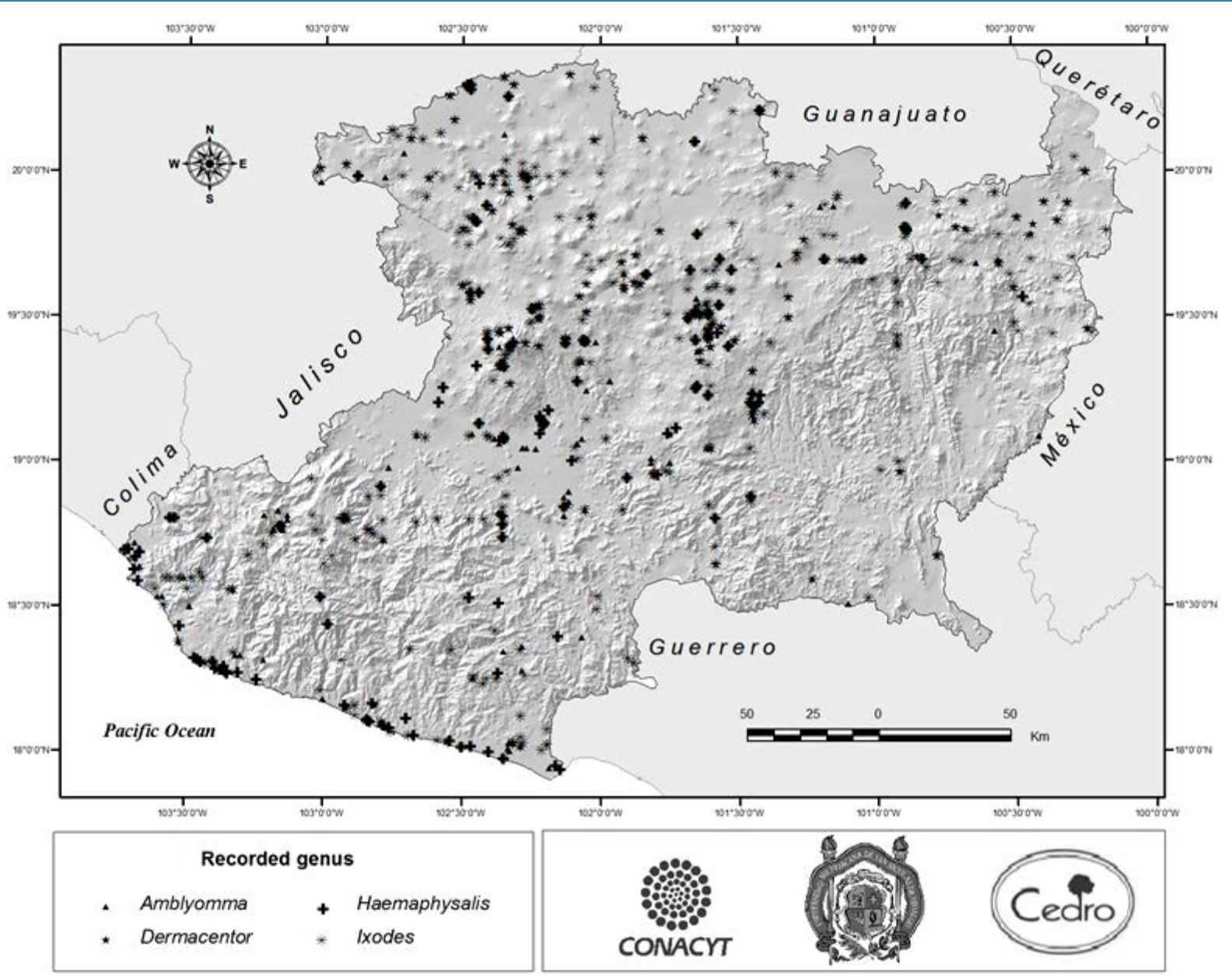

Figure 3. Geographic distribution of the localities of real and potential hosts of tick genus of the family Ixodidae in Michoacán state.

- Host species for the genus Amblyomma are widely distributed throughout the state and do not display any environmental preference, being found in warm, temperate, dry or humid climates, in any geomorphologic situation (mountains, plains, valleys, piedmonts), and in any soil or vegetation types. The same pattern is observed for the hosts of genus Haemaphysalis.

- Host species for the genus Dermacentor are strongly associated temperate climate and its only record in the Sierra-Costa region is on mountain slopes where the climate is less warm.

- Hosts of the species of the genus Ixodes have the most varied associations. Some hosts have only been found in temperate climate and others in warm zones, while over half of the host may be found in any hydro-climatic or geoecological condition; i.e., they may be found in any part of the state regardless of geology, relief, soil, vegetation, climate, etc.

It is important to point out that the map in Figure 3 only displays the information related to the distribution of hosts of ticks of the Ixodidae family present in the wild fauna. For that reason, the zones occupied by cultivated or induced grasslands appear in the map as without reports of ticks. This suggests that when adding records of ticks found in domestic animals at present [35], it will be necessary to increase the scale of the map in order to appreciate the geographic distribution of such records at an adequate resolution.

In Table 3 and Figure 4 show the results of the distribution of the categories of species richness of the family Ixodidae in the state of Michoacán. These results were calculated using the areas of the polygons where documented hosts of these ticks had been recorded. The potential species richness class Very Low, which comprises up to five species of ticks, had an ample predominance in the state's territory covering over $70 \%$ of the zones with reports of wild hosts, being found both in areas having a temperate climate and in the warm coastal 
Table 3. Distribution of the potential species richness (R) of ticks in the family Ixodidae for the state of Michoacán for natural breaks method.

\begin{tabular}{cccc}
\hline & \multicolumn{2}{c}{ Species richness area } & \\
\hline Classes & No. of species & $\mathrm{km}^{2}$ & $\%$ \\
\hline Very Low & $\mathrm{R} \leq 5$ & 14553.8 & 70.32 \\
Low & $6 \leq \mathrm{R} \leq 9$ & 2950.4 & 14.25 \\
Medium & $10 \leq \mathrm{R} \leq 13$ & 1805.5 & 8.71 \\
High & $14 \leq \mathrm{R} \leq 17$ & 843.8 & 4.08 \\
Very High & $\mathrm{R} \geq 18$ & 547.6 & 2.64 \\
Total & & 20701.1 & 100 \\
\hline
\end{tabular}

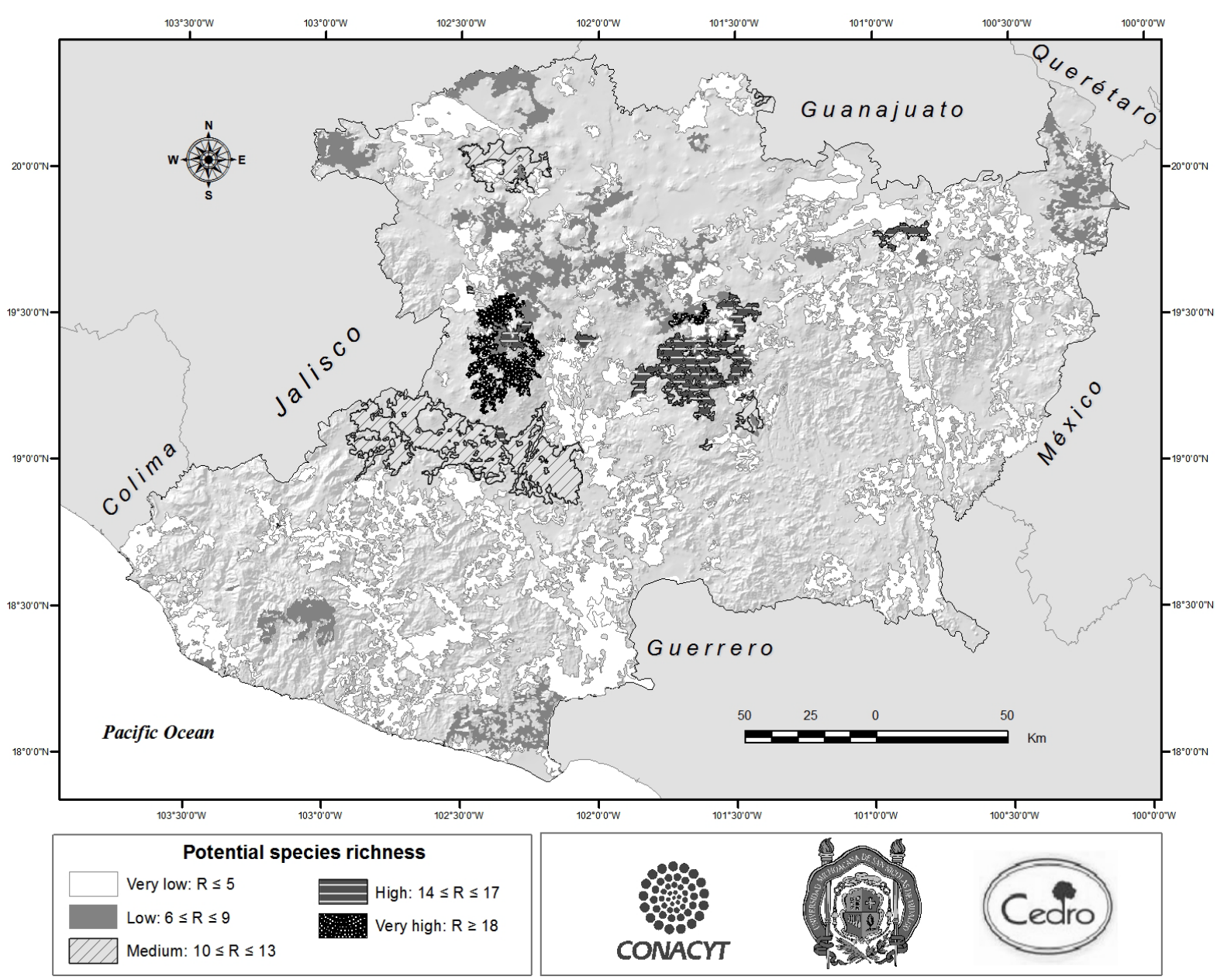

Figure 4. Potential species richness of ticks in the family Ixodidae in the wild fauna from the state of Michoacán, Mexico.

zones. The species richness class Low had a distribution having a pattern similar to the above category, but occupying a much smaller area. Beginning in the species richness class Medium, a strong concentration of polygons was appreciated with a noticeable reduction in distribution areas. The species richness class Medium was localized towards the central zone of the state, with a polygon located to the northeast, always in association with temperate climate zones. The species richness class High was concentrated in the center of the state and in a polygon near the border with the state of Guanajuato in northern Michoacán. The species richness class Very 
High occupied an area south of Los Reyes and west of Uruapan, coincident with the Pico de Tancítaro. This area presented the only known collection sites of Ixodes tancitarus in Michoacán.

For a full understanding of the epidemiology, distribution and richness of ticks and their potential transmitted pathogens; it is essential understand the complex interaction between ticks, their host, their environment and the pathogens which they transmit over a long period to be able to determine annual variation [36].

Our method predicted that a total of 31 species of ixodids was hosts by wild animals from Michoacán. Some species had very few collection sites for their hosts, while other host species of ticks were likely to be abundantly distributed throughout the state regardless of climatic or other environmental conditions. Inclusion of ixodid present in cattle and other domestic animals will likely require changing to a more detailed geographic scale.

\section{Conclusions}

The spatial category of maximum species richness is correlated with deterioration of the host's habitat. According to the results of Cuevas [37], the areas having the largest potential concentration of ixodid species, i.e., the better conserved zones within Natural Protected Areas have a 90\% probability of suffering land use changes in the next coming years. This means that the zones of High and Very High species richness of ticks of the family Ixodidae in the wild fauna may experience a severe affectation of their ecosystems and increased activity by humans and livestock in these areas may result in domesticated animals coming in contact with unfamiliar species of ticks and the pathogens they carry, with all the implied zoo sanitary risks of this migration of hosts; as exemplified by the Lyme disease.

The forecasts of land use changes indicate that many areas presently occupied by these ticks and their hosts are strongly threatened, which implies potential risks of induced migration of the ticks to the domestic fauna, cattle and even to humans. Due to the recent examples of emerging diseases associated with transmissions of pathogenic organisms from animals to humans [38], it is necessary to complete the taxonomic records of these invertebrates and to adopt more detailed scales of spatial analysis.

The spatial configuration of the potential distribution of ticks obtained in the present work may be an initial guide for future cartographic hypotheses about the geographic distribution of species in the family Ixodidae in the state of Michoacán, and thus provides the basis for the design of sampling efforts and, furthermore, defines initial spatial priorities of tick management and control.

Studies of ticks in Michoacan and their evolution over time are not enough, because a slower rate of progression of taxonomic work and a high rate of environmental change may involve a high risk of local extinction, it's why we used a predictive model to estimate the potential distribution species, and the likely impact of environmental consequences. The predictive nature of such proposals can only be verified by intensifying the field and checking the presence of the species that were predicted in a given region.

\section{Acknowledgements}

The first author acknowledges the ample support for the present research received from the CONACyT Project 90039 "Inventario y distribucióngeográfica de garrapatas de la familia ixodidae en el estado de Michoacán" and the PROMEP Nuevo PTC 257 Project. We would also like to thank an anonymous reviewer who enriched the paper.

\section{References}

[1] De la Fuente, J., Estrada-Peña, A., Venzal, J.M. and Sonenshine, D.E. (2008) Overview: Ticks as Vectors of Pathogens That Causes Diseases in Humans and Animals. Frontiers in Bioscience, 13, 6938-6946. http://dx.doi.org/10.2741/3200

[2] Keirans, J.E. and Durden, L.A. (1998) Illustrated Key to Nymphs of the Tick Genus Amblyomma (Acari: Ixodidae) Found in the United States. Journal of Medical Entomology, 35, 389-495.

[3] Vázquez, G.L. (1987) Zoología del PhylumArthropoda. 6th Edición, Trillas, México, DF.

[4] Aktas, M. (2014) A Survey of Ixodid Ticks Species and Molecular Identification of Tick-Borne Pathogens. Veterinary Parasitology, 200, 3-4. http://dx.doi.org/10.1016/j.vetpar.2013.12.008

[5] Guglielmone, A.A., Robbins, R.G., Apanaskevich, D.A., Petney, T.N., Estrada-Peña, A., Horak, I.G., Shao, R. and Barker, S.C. (2010) The Argasidae, Ixodidae and Nuttalliellidae (Acari: Ixodida) of the World: A List of Valid Species 
Names. Zootaxa, 2528, 1-28.

[6] Hoffmann, A. (1962) Monografía de los Ixodoidea de México 1 parte. Revista de la Sociedad Mexicana de Historia Natural, 23, 191-307.

[7] Woodham, C.B., González, O., López, L. and Guereña, M.R. (1983) Progresos en la erradicación de las garrapatas Boophilus en México 1960-80. Revista Mundo de la Zootecnia, 43, 18-23.

[8] Guzmán-Cornejo, C., Pérez, T.M., Nava, S. and Guglielmone, A.A. (2006) First Records of the Ticks Amblyommacalcaratum and A. pacae (Acari: Ixodidae) Parasitizing Mammals of Mexico. Revista Mexicana de Biodiversidad, 77, 123-127.

[9] Guzmán-Cornejo, C., Robbins, R.G. and Peréz, T.M. (2007) The Ixodes (Acari: Ixodidae) of Mexico: Paratite-Host and Parasite-Host Checklists. Zootaxa, 1553, 43-58.

[10] Guzmán-Cornejo, C. and Robbins, R.G. (2010) The Genus Ixodes (Acari: Ixodidae) in Mexico: Adult Identification Keys, Diagnoses, Hosts, and Distribution. Revista Mexicana de Biodiversidad, 81, 289-298.

[11] Vargas, M., Gordillo-Pérez, G., Solórzano, F., Rivera, A., Polaco, O.J., Muñoz, O. and Torres, J. (2007) Evidencias de Borrelia burgdorferi Sensu stricto en garrapatas del Noreste de México. Entomología Mexicana, 6, 830-835.

[12] Hoffmann, A. and López-Campos, G. (2000) Biodiversidad de los ácaros en México. CONABIO-UNAM, México, D.F.

[13] Cuevas, G. (2005) Pronóstico del cambio de uso del suelo en áreas forestales del estado de Michoacán. Tesis de Licenciatura en Geografía. Facultad de Filosofía y Letras de la Universidad Nacional Autónoma de México, México, D.F.

[14] Sosa-Gutierrez, C.G., Quintero, M.T., Gaxiola, C.S., Cota, G.S., Esteve-Gassent, M.D. and Gordillo-Perez, M.G. (2013) Frequency and Clinical Epidemiology of Canine Monocityc Ehrlichiosis in Dogs Infested with Ticks from Sinaloa, Mexico. Journal of Veterinary Medicine, 2013, Article ID: 797019. http://dx.doi.org/10.1155/2013/797019

[15] Sosa-Gutiérrez, C.G. Vargas, M., Torres, J. and Gordillo-Pérez, M.G. (2014) Tick-Borne Rickettsial Pathogens in Rodents from Mexico. Journal of Biomedical Science and Engineering, 7, 884-889. http://dx.doi.org/10.4236/jbise.2014.711087

[16] Estrada-Peña, A. (2002) A Simulation Model for Environmental Population Densities, Survival Rates and Prevalence of Boophilus decoloratus (Acari: Ixodidae) Using Remotely Sensed Environmental Information. Veterinary Parasitology, 104, 51-78. http://dx.doi.org/10.1016/S0304-4017(01)00607-0

[17] Daniel, M., Kolar, J. and Zeman, P. (2008) Analyzing and Predicting the Occurrence of Ticks and Ticks-Borne Diseases Using GIS. In: Bowman, A.S. and Nuttall, P.A., Eds, Ticks: Biology, Disease and Control, Cambridge University Press, Cambridge, 377-407. http://dx.doi.org/10.1017/CBO9780511551802.018

[18] INEGI (2001) Marco Geoestadístico Municipal. Instituto Nacional de Estadística y Geografía (INEGI), Aguascalientes.

[19] Cooley, R.A. and Kohls, G.M. (1942) Ixodes mexicanus n. sp. y Ixodes tancitarus n. sp., dos nuevas garrapatas mexicanas (Acarina, Ixodidae). Revista de la Sociedad Mexicana de Historia Natural, 3, 149-154.

[20] Vázquez, L. (1946) Ixodes scuticrenatus una especie nueva de garrapata de México. Anales del Instituto de Biologia Mexico, 171-172, 237-245.

[21] Kohls, G.M. and Clifford, C.M. (1966) Three New Species of Ixodes from Mexico and Description of the Male of $I$. auritatus Auritatus Newmann, I. conepati Cooley and Kohols and I. lasallei Mendez and Ortiz (Acari: Ixodidae). The Journal of Parasitology, 52, 810-820. http://dx.doi.org/10.2307/3276462

[22] Jones, E.K., Clifford, C.M., Keirans, J.E. and Kohls, G.M. (1972) The Ticks of Venezuela (Acari: Ixodiodea) with a Key to the Species of Amblyomma in the Western Hemisphere. Brigham Young University Science Bulletin, 38 p.

[23] Keirans, J.E. and Jones, E.K. (1972) Description of the Immature Stages of Ixodes (I.) Sinaloa Kohlsy Clifford (Acarina: Ixodidae), from Rodents in Mexico and Nicaragua. Acarologia, 13, 471-475.

[24] Genoway, H.H. (1973) Systematics and Evolutionary Relationships of Spiny Pocket Mice, Genus Liomys (Special Publication). Texas Tech University Press, Lubbock.

[25] Vargas, M., Cervantes, F.A., Montiel-Parra, G. and Rubio-Hernández, S. (2010) Ectosimbiontes de Sorexsaussurei del Estado de Veracruz, México. In: Cervantes, F.A., Vargas-Cuenca, J. and Hortelano-Moncada, Y., Eds., 60 años de la Colección Nacional de Mamíferos del Instituto de Biología, UNAM. Aportaciones al Conocimiento y Conservación de los Mamíferos Mexicanos, Instituto de Biología, UNAM, México, D.F., 265-270.

[26] SPP-INEGI (1984) Carta Geológica de los Estados Unidos Mexicanos a escala 1:250,000 (Digital Version). Dirección General de Geografía, 124.

[27] Ortiz, M.A. (2000) Sistema Clasificatorio del Relieve de México, escala 1:250,000. Instituto Nacional de Ecología de 
la SEMARNAT e Instituto de Geografía de la UNAM.

http://www.inegi.org.mx/geo/contenidos/recnat/geologia/infoescala.aspx

[28] García, E. (1998) Carta de climas de la República Mexicana a escala 1:1000,000, versión digital. Comisión Nacional para el Conocimiento y Uso de la Biodiversidad (CONABIO), México.

[29] SPP-INEGI (1984) Carta Edafológica de los Estados Unidos Mexicanos a escala 1:250,000 (Digital Version). Dirección General de Geografía, 121.

[30] Velázquez-Montes, A., Mas, J.F. and Palacio-Prieto, J.L. (2002) Uso de suelo y vegetación 2000, Escala 1:250,000. Instituto Nacional de Ecología e Instituto de Geografía de la UNAM. http://mapas.ine.gob.mx/est_uso_suelo.html

[31] CONABIO (2006) Bases de datos de flora y fauna de México. Sistema de Información Biótica Ver. 4.5, Fideicomiso Fondo para la Biodiversidad. Comisión Nacional para el Conocimiento y Uso de la Biodiversidad (CONABIO). http://www.conabio.gob.mx/biotica/cms/index.php

[32] Keirans, J.E. and Litwak, T.R. (1989) Pictorical Key to the Adults of Hard Ticks, Family Ixodidae (Ixodida: Idodidae) East of the Mississippi River. Journal of Medical Entomology, 26, 435-448.

[33] Kohls, G.M. (1958) Amblyomma Imitator, a New Species of Ticks from Texas and Mexico and Remarks on the Synonymy of A. Cajennense (Fabricius) (Acarina-Ixodidae). The Journal of Parasitology, 44, 430-433. http://dx.doi.org/10.2307/3274329

[34] ESRI (1999) Arc View Ver. 3.3, GIS. Environmental Systems Research Institute (ESRI), Inc.

[35] Gil-Luna, I., Vargas, M. and González, I. (2009) Inventario de garrapatas duras (Familia Ixodidae) en nueve municipios de Michoacán. En: Memorias del Encuentro Nacional Sobre Biodiversidad, Conservación y Restauración Ecológica en México. CD, Morelia.

[36] Ostfeld, R.S., Caham, C.D., Oggenfus, K., Winchcombe, R.J. and Keesing, F. (2006) Climate, Deer, Rodents and Arcorns as Determinants of Variation in Lyme-Disease Risk. PLoS Biology, 4, E145. http://dx.doi.org/10.1371/journal.pbio.0040145

[37] Cooley, R.A. and Kohls, G.M. (1944) The Genus Amblyomma (Ixodida) in the United States. The Journal of Parasitology, 30, 77-111. http://dx.doi.org/10.2307/3272571

[38] Gordillo-Pérez, G., Vargas, M., Solorsano-Santos, F., Rivera, A., Polaco, O.J., Alvarado, L., Muñóz, O. and Torres, J. (2009) Demostration of Borrelia burgdorferi sensu stricto Infection in Ticks from the Northeast of Mexico. Clinical Microbiology and Infection, 15, 496-498. http://dx.doi.org/10.1111/j.1469-0691.2009.02776.x

[39] Gaxiola, S.M., Obregón, I.F., Quintero, M.T., Cabrera, I.A. and Rubio, M.C. (1997) Prevalencia de Rhipicephalus sanguineus en canidos de dos colonias de diferente nivel socio económico de Culiacán Sinaloa. Proceedings of the 13th Congreso Latinoamericano de Parasitología, La Habana, 17-23 November 1997. 
Scientific Research Publishing (SCIRP) is one of the largest Open Access journal publishers. It is currently publishing more than 200 open access, online, peer-reviewed journals covering a wide range of academic disciplines. SCIRP serves the worldwide academic communities and contributes to the progress and application of science with its publication.

Other selected journals from SCIRP are listed as below. Submit your manuscript to us via either submit@scirp.org or Online Submission Portal.
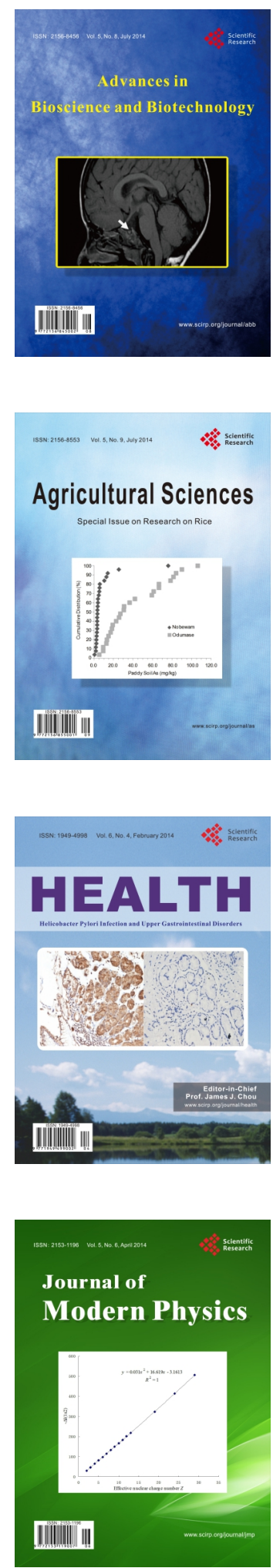
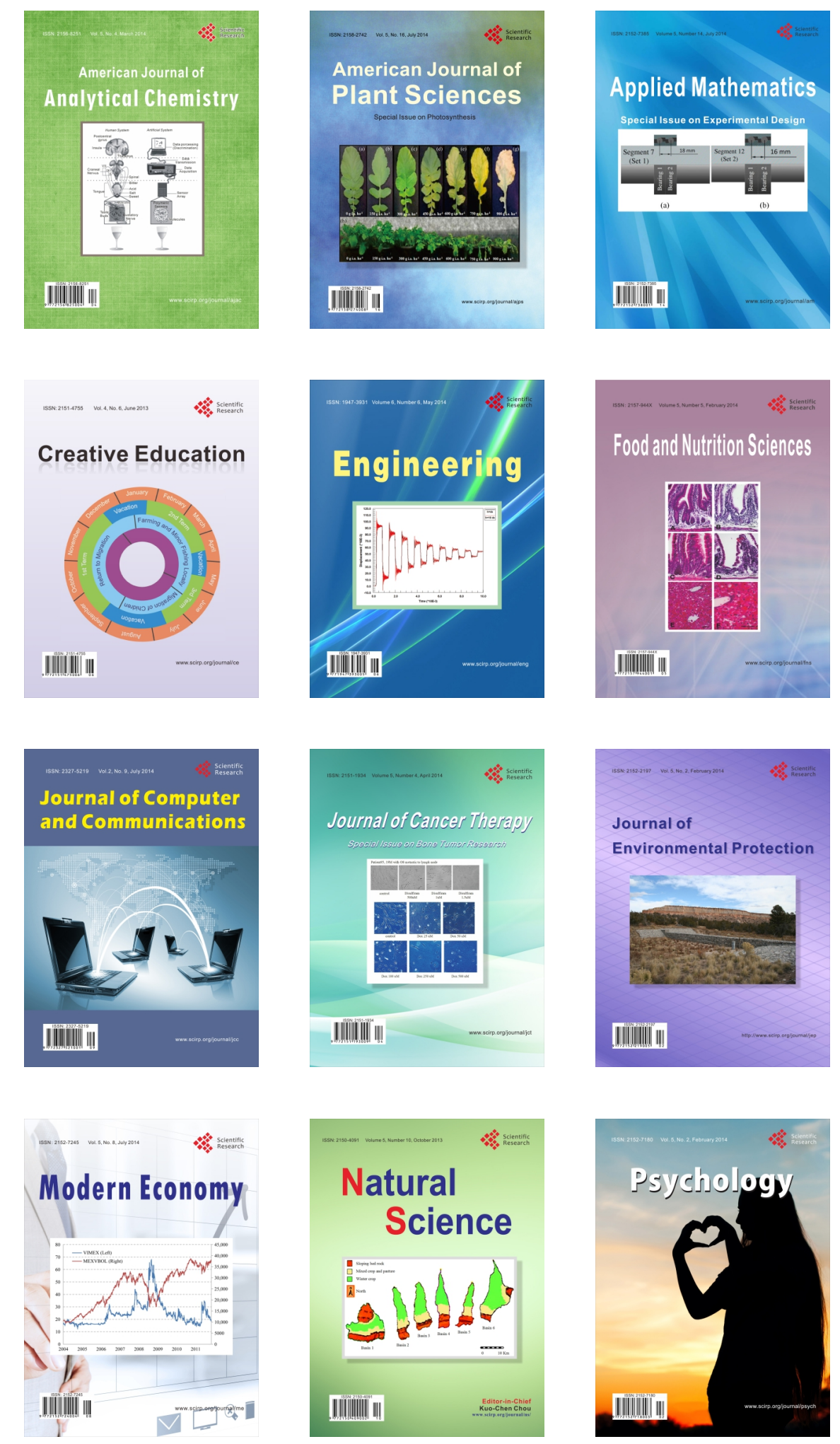